\title{
Article
}

\section{History and Technology of Terra Preta Sanitation}

\section{Sabino De Gisi ${ }^{1, *}$, Luigi Petta ${ }^{1}$ and Claudia Wendland ${ }^{2}$}

1 Italian National Agency for New Technologies, Energy and Sustainable Economic Development, ENEA, Water Resource Management Lab., via Martiri di Monte Sole 4, Bologna (BO) 40129, Italy; E-Mail: luigi.petta@enea.it

2 Women in Europe for a Common Future, WECF, St. Jakobsplatz 10, Munich 80331, Germany; E-Mail: claudia.wendland@wecf.eu

* Author to whom correspondence should be addressed; E-Mail: sabino.degisi@enea.it; Tel.: +3-905-160-989-26; Fax: +3-905-160-983-09.

Received: 12 December 2013; in revised form: 30 January 2014 / Accepted: 4 March 2014 / Published: 12 March 2014

\begin{abstract}
In order to reach the Millennium Development Goals for significantly reducing the number of people without access to adequate sanitation, new holistic concepts are needed focusing on economically feasible closed-loop ecological sanitation systems rather than on expensive end-of-pipe technologies. An analysis of a former civilization in the Amazon (nowadays Brazil) highlights the possibility to close the loop with a more sustainable lifestyle integrating soil fertility, food security, waste management, water protection and sanitation, renewable energy. Terra Preta do Indio is the anthropogenic black soil produced by ancient cultures through the conversion of bio-waste, fecal matter and charcoal into long-term fertile soils. These soils have maintained high amounts of organic carbon several thousand years after they were abandoned. Deriving from these concepts, Terra Preta Sanitation (TPS) has been re-developed and adopted. TPS includes urine diversion, addition of a charcoal mixture and is based on lactic-acid-fermentation with subsequent vermicomposting. Lacto-fermentation is a biological anaerobic process that generates a pre-stabilization of the mixture. The main advantage of lacto-fermentation is that no gas and no odor is produced. What makes it particularly interesting for in-house systems even in urban areas. Instead, vermicomposting is an aerobic decomposition process of the pre-digested materials by the combined action of earthworms and microorganisms. It transforms the carbon and nutrients into the deep black, fertile and stable soil that can be utilized in agriculture. No water, ventilation or external energy is
\end{abstract}


required. Starting from ancient Amazonian civilizations traditional knowledge, the aim of this work is to present TPS systems adopted nowadays.

Keywords: biochar; ecosan; nutrient recovery; reuse; sustainability; terra preta; traditional knowledge

\section{Introduction}

The modern misconception that human excreta are waste with no useful purpose has resulted in the end of-pipe sanitary systems that we have today. In nature however, there is no waste. All products of living things are used as raw materials by others as part of a cycle.

"Considering the environmental damage, the health risks, and the worsening water crisis, resulting from our present sanitary practices, a revolutionary rethink is urgently needed if we are to correct this misconception. In this way we realistically have a chance of achieving the Millennium Development Goals (MDG) of providing sustainable sanitary services to over 1.2 billion people" [1]. In light of the current discussion around the post-MDG and targets for sanitation, there is a strong will to include a requirement for the re-use of human excreta in agriculture into the new term "adequate sanitation" replacing the current insufficient term "improved sanitation" [2].

A new paradigm is required in sanitation, based on ecosystem approaches and the closure of material flow cycles rather than on linear, expensive and energy intensive technologies. This paradigm must recognize human excreta and water from households not as a waste but as a resource that should be made available for reuse [3]. Such ecological sanitation systems are based on the systematic implementation of the reuse and recycling of nutrients, organic matter and wastewater as a hygienically safe, closed-loop and holistic alternative to conventional solutions.

Moreover, ancient water and wastewater technologies may have the potential to furnish "new" and sustainable solutions relevant to the current global environmental crisis [4]. In fact, many features of ancient systems (including no power requirements, use of locally-available materials and low or absent mechanization) mean they are arguably suitable for utilization as low-cost and low-maintenance water and sanitation technologies (WATSAN), particularly in the developing world [5]. Therefore, it is important to analyze and rediscover the ancient traditional knowledge using them for the new challenges such as the sustainable management of natural resources. The sustainability of societies depends essentially on secured water resources, food supply and an intelligent management of wastes. Food, for example, is produced with extensive input of energy and resources while nutrients are detracted from soils and needs to be replaced. Generally, replacement is often done by artificial fertilizers, which are produced with high energy input. In addition, the reduction of organic matter content by the degradation of humus is mostly not replaced to the required extent. A slow but steady degradation of soil as well as a loss of fertility are due from these reasons and pose a severe risk to long term food security worldwide [6].

In this context, the objective of this study is to present Terra Preta Sanitation systems (TPS) adopted nowadays also investigating the traditional knowledge of the ancient Amazonian civilizations. 


\section{History of Terra Preta}

An analysis of a former civilization in the Amazon, nowadays Brazil (see Figure 1), reveals concepts which enable a highly efficient handling of organic wastes. Terra Preta do Indio is the anthropogenic black soil that was produced by ancient cultures through the conversion of bio-waste and fecal matter into long-term fertile soils.

These soils have maintained high amounts of organic carbon even several thousand years after they were abandoned [6]. Radiocarbon dating indicates that these soils were formed between 7000 and 500 cal years B.P. and are of pre-Columbian origin [7]. A hectare of meter-deep Terra Preta can contain 250 tons of carbon as opposed to 100 tons in unimproved soil [6].

Figure 1. Terra Preta do Indio in Brazil: (a) South America chorography; (b) Map of the Terra Preta sites; (c) Patterns of Terra Petra sites near Belterra (modified by Gerhard Bechtold [8]).

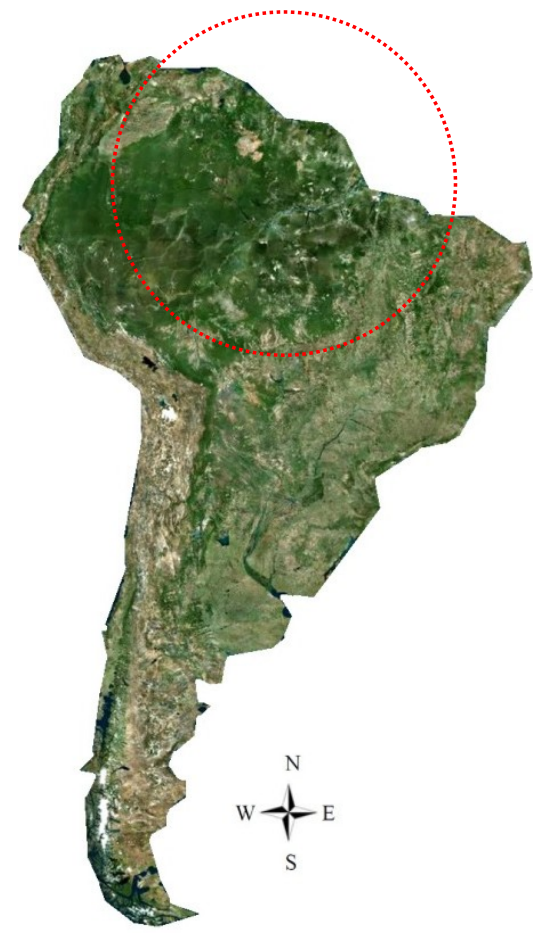

(a)

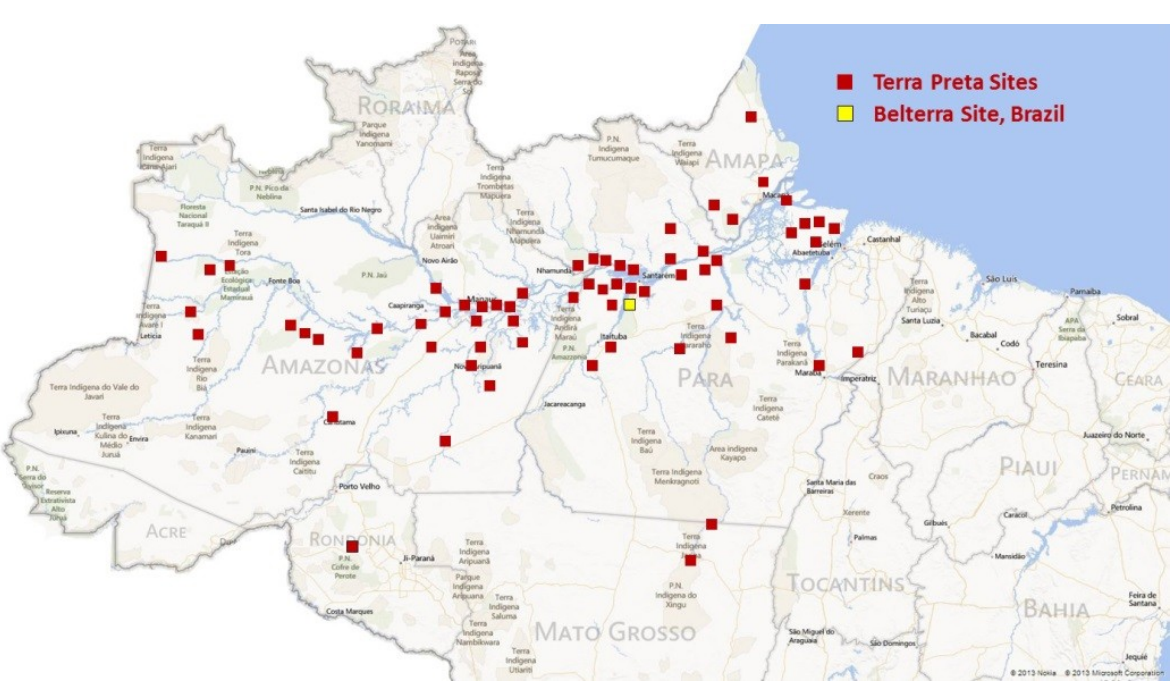

(b)

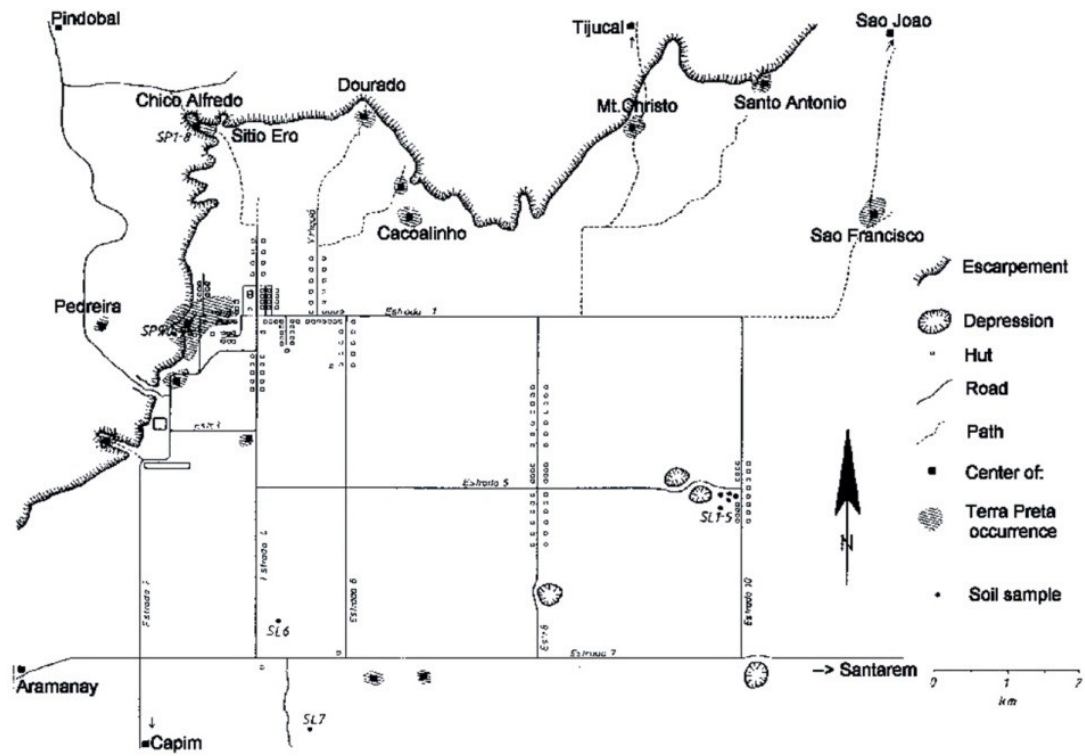

(c) 
Due to the accumulation of charred biomass and other organic residues, Terra Preta subsequently formed giving it a deep, distinctly dark and highly fertile soil layer in order to be productive without using fertilizers.

From evidence of excavations and laboratory results, it was concluded that this culture had a superior sanitation and bio-waste system. This is due to the source separation of fecal matter, urine and clever additives (particularly charcoal dust) as well as treatment steps for the solids resulting in high yielding gardening. Additives included ground charcoal dust while the treatment and smell prevention started with anaerobic lactic-acid fermentation followed by vermicomposting.

According to Brewer and Brown (2012) [9], from Orellana's time until the middle of the nineteenth century, explorers passing through the central Amazon region did not make reference to the dark soils or the soil management practices of the natives in their writings.

In the 1870s, several English-speaking geologists began making comments about fertile dark soils on sites of previous native villages while the first to record the term Terra Preta or dark soil were Briton C. Barrington Brown and William Lidstone. Figure 2a,b showed the network of roads connecting villages in the virgin forest and a graphical reconstruction of an indigenous Amazonian village, respectively.

In 1879, Charles Hartt and Herbert Smith referred to dark soil areas as "kitchen middens" due to the amount of pottery found and the assumption that the fertility was caused by high organic residue deposition. Figure 2c shows sample soil profiles of Terra Preta soils and a typical jungle oxisol soil. Dark soil layers can be up to several meters thick, and cover patches from a few square meters to several square kilometers in size.

Figure 2. Terra Preta do Indio in Brazil: (a) Networks of roads connect villages in the virgin forest [10]; (b) Graphic reconstruction of an indigenous Amazonian village; (c) In the left a nutrient-poor oxisol while in the right an oxisol transformed into fertile Terra Preta [11].

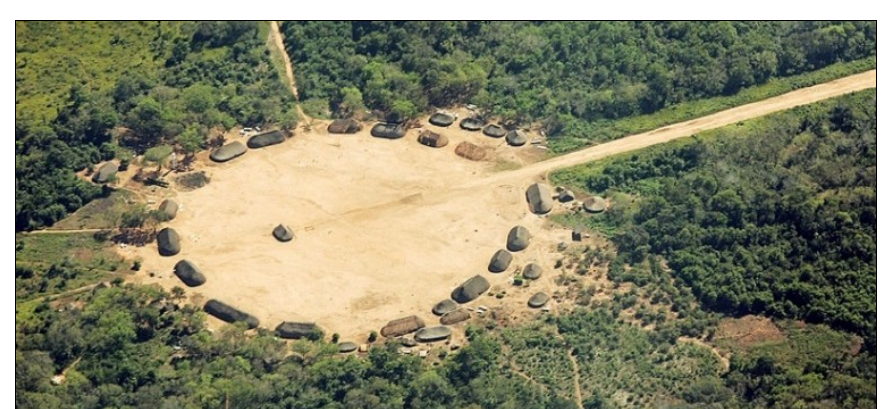

(a)

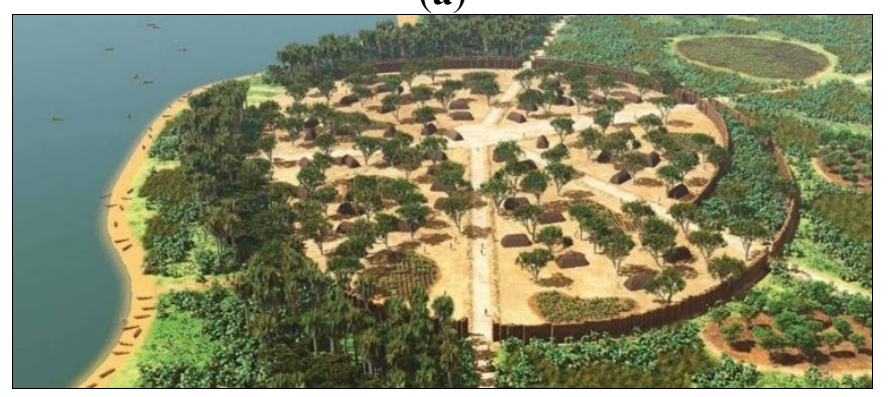

(b)

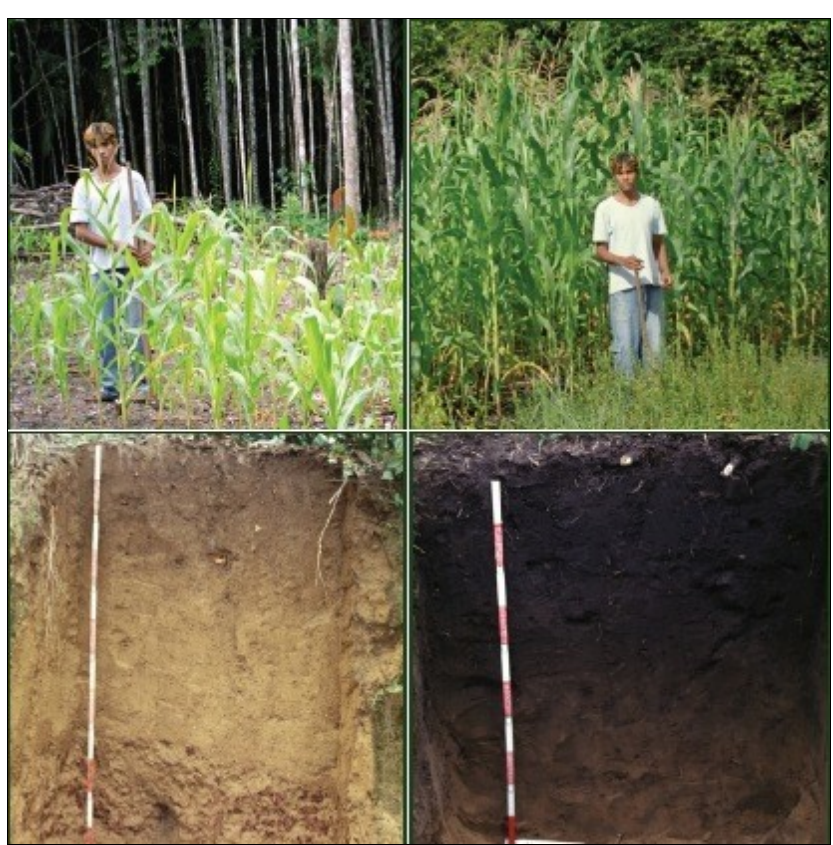

(c) 
In 1903, Friedlich Katzer, in his book on Amazon geology (published in Leipzig, Germany), was the first to report extensive analytical data based on his fieldwork in the lower Amazon, south of Santarém. Katzer described the Amazonian dark soils as containing decomposed organic matter, mineral residues and charred plant material.

Nearly a century ahead of his time, Katzer concluded that the high organic matter content of the dark earths showed that the soils were different from the surrounding jungle soils, but at the same time, they were made by human activity.

Among the theories was that: (1) Terra Preta came from volcanic ash; (2) the fertile sites were locations of former lakes and ponds that had accumulated organic matter and therefore attracted artifact-leaving native farmers; (3) the dark soils were the results of repetitive short-term settlements. In 1966, Wim Sombroek described and provided laboratory analysis results for the dark soils of the Belterra Plateau, whose maps are visible in Figure 1c. Sombroek introduced the term terra mulata or brown soil to describe the high-organic-matter soils often surrounding Terra Preta soils and likely the sites of field agriculture of ancient natives. Unlike Terra Preta soils, which were more likely waste disposal zones, terra mulatas are slightly lighter in color, contain few artifacts, have lower concentrations of plant nutrients, and appear to be the result of semi-intensive cultivation over long periods of time, containing material from low-temperature field burning.

Additional information about terra mulata is reported in Brewer and Brown [9]. Since 2000, numerous works have been published describing Terra Preta sites and soil management practices throughout South America.

Among the key findings, we report the following:

- Black carbon in soils is the key to Terra Preta's long organic matter residence times and continuing fertility [7];

- Charcoal additions alone were not nearly as effective as combinations charcoal and organic amendments (chicken manure, compost, kitchen scraps) applied to the soil [12].

The above statements highlighted the role of charcoal as carbon source for a sustainable agriculture. Charcoal for heating and other purposes is traditionally made by slow pyrolysis characterized by the following parameters: temperature range of $350-800{ }^{\circ} \mathrm{C}$, heating rate less than $10{ }^{\circ} \mathrm{C} \min ^{-1}$, atmospheric pressure, hours-days as residence time and char as primary product [9]. Process occurs in the absence of oxygen to moderate or high temperatures, with slow heating rates and long residence times. Necessary heat to start and drive the reaction is usually provided internally by combusting a portion of the feedstock.

The goal of slow pyrolysis is a high-carbon, energy-dense solid char product. The co-products are a watery, low-molecular-weight acidic liquid called pyroligneous acid or wood tar, and a low-energy, combustible gas. Charcoal production has existed in the repertoire of human technologies for thousands of years. In early fire pits, bits of charcoal would have been left over after a fire, especially if the center of larger pieces did not burn completely. Humans gradually learned that they could produce more of this black, light, and friable material if they covered burning wood or debris.

Some of the first techniques to produce charcoal, such as in pit kilns or mound kilns, were used through the early twentieth century, and are still practiced in developing countries around the world. Figure 3 show an example of mound kiln for biochar production, used by the ancient Amazonian 
civilization. Its construction involves that a large, tall piece of wood is set vertically in the center surrounded by small, easily ignited wood pieces. Around the center post are stacked progressively shorter and smaller logs, all vertically arranged with small pieces packed in between. As was done with the pit kiln, the mound is then covered with a layer of branches and leaves, followed by soil. The center $\log$ is removed to serve as a flue and the fire is ignited by dropping burning material into the center opening. The burn/carbonization process is controlled by opening or sealing holes in the soil layer along the bottom edges of the mound as visible in Figure 3a. Additional information about the charcoal production is reported in Brewer and Brown [9].

Figure 3. (a) Example of a mound kiln (scale $=4 \mathrm{~m}$ ). Modified by Brewer and Brown [9];

(b) Biochar [13].

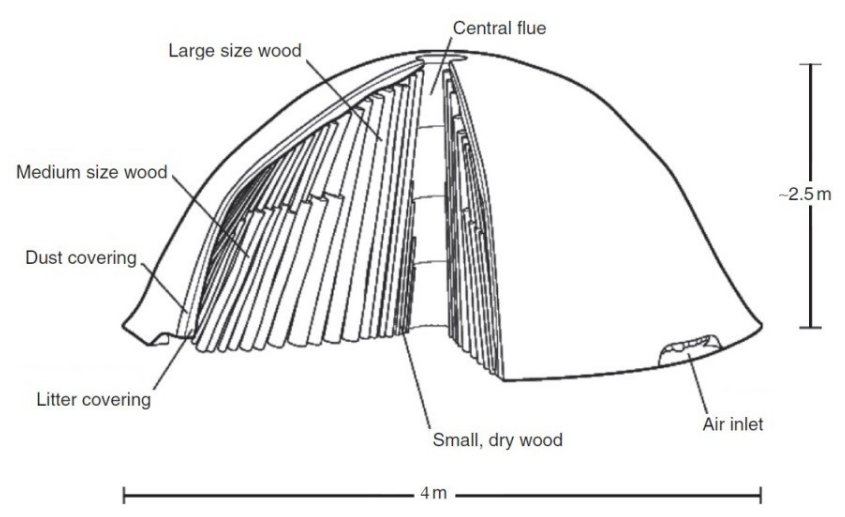

(a)

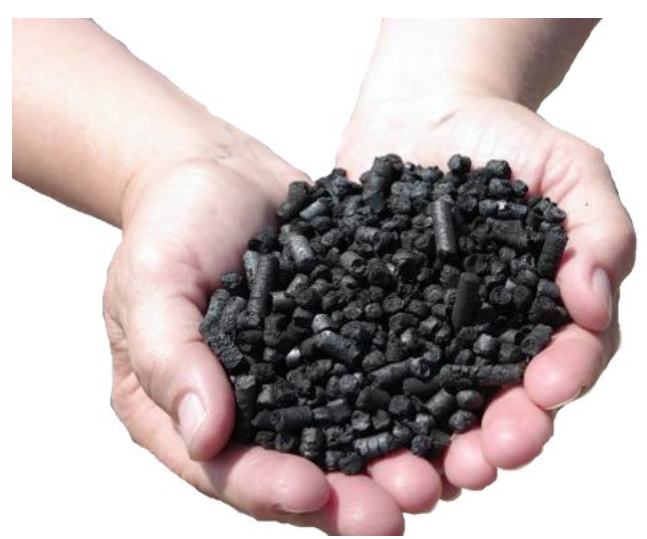

(b)

Today, there is much research running about biochar as it serves as agriculture soil conditioner and long term improvement as well as climate friendly because of capturing $\mathrm{CO}_{2}$. For example, biochar can also produced by fecal matter [14], but the biochar aspect is not major part of this study.

\section{Terra Preta Sanitation Systems}

The adoption TPS systems, based on the safe treatment of human waste, could be the basis for sustainable agriculture in the twenty-first century in order to produce sustainable soils, sanitation systems and food for billions of people instead of chemical as visible in Figure 4.

Figure 4. The four spheres of the Terra Preta Sanitation system (TPS).

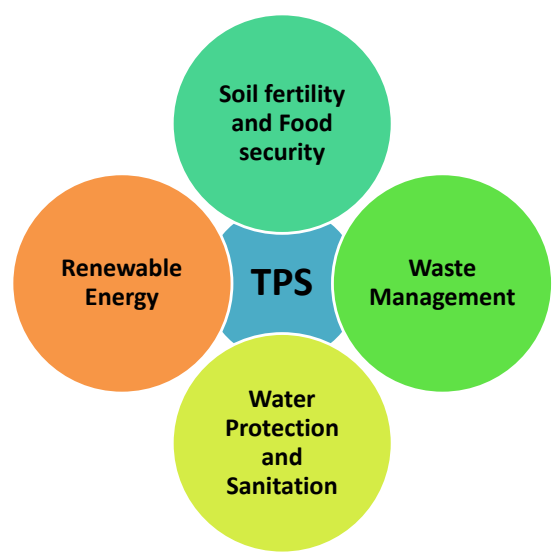


The idea of Terra Petra Sanitation (TPS) is to produce fertile soils of human excreta. Although a number of researches are being done, it is not clear what toilet system the Amazonians used.

However, the challenge of today is how to integrate Terra Preta (TP) into the sanitation chain, which is acceptable, affordable and sustainable. There are different approaches how to implement TPS:

- Dry TPS systems;

- Systems with flush water.

\subsection{Dry TPS Systems (without Flush Water)}

It is a low-cost dry sanitation system either with or without urine diversion. Through biological processes of lacto-fermentation, charcoal addition and vermicomposting human excreta are converted into Terra Preta like soils subsequently used in agriculture.

The inclusion of urine is preferable as urine contains most of the valuable macro and micro nutrients. Moreover, to treat the collected urine jointly with the fecal matter in the toilet it is a challenge. Therefore in most concepts, the urine diversion dry toilet (UDDT) toilet is recommended, to collect the urine separately which is a well known and accepted system [15] and to add it afterwards such as shown in Figure 5.

Vermicomposting is considered as important post treatment step: a decomposition process involving the combined action of earthworms and microorganisms. At that regard, Shalabi [16] provided an exhaustive review of the theoretical background of the vermicomposting process, mechanisms and practical application methods.

In TPS systems urine and feces are collected in 2 separate compartments as shown in Figure 5. Urine is collected in a jerrican and feces fall into a bucket that is placed airtight underneath the toilet bowl to allow for anaerobic conditions in the bucket. After each defecation, a mix of charcoal powder together with a finely cut wood source and some limestone/volcanic soil needs to be added to cover the feces. In addition, a few dashes of a lacto-bacilli containing microbial mix should be added as reported in Factura et al. [6].

"The first step in TPS system is lactic acid fermentation (or lacto-fermentation) followed by a second step of vermicomposting. Lacto-fermentation is similar to the silage production process in agriculture and involves urine and feces separately as visible in Figure 5. Lacto-fermentation is a biological anaerobic process (like anaerobic digestion) that generates a pre-stabilization of the mixture. With reference to the treatment of feces, it is more appropriate to use the term of "fermentation of semi-dry fecal matter". In fact, with the addition of charcoal and wood chips to feces after each defecation, a large amount of moisture is adsorbed. Generally, the total solids (TS) are in a range of 15\%-25\%, typical of semi-dry anaerobic digestion processes with a Hydraulic Retention Time (HRT) of 25-30 days [17].

Although the frequent opening of the lid, the success of the lacto acid fermentation is also due to the nature of lactic acid bacteria as reported in Madigan and Martinko [18]. In fact, these bacteria have the advantage of not being sensitive to $\mathrm{O}_{2}$ (they are aero tolerant) allowing them to grow in its presence as well as in its absence.

The two most important subgroups of the lacto-fermentation and lactic acid bacteria lies in the nature of the products formed from the fermentation of sugars. The first, called homofermentative 
produces a single fermentation product, lactic acid. While the second, called heterofermentative, produces other products, mainly ethanol and $\mathrm{CO}_{2}$ as well as lactate [18].

As regard to the treatment of urine by lacto-fermentation, the controlled metabolization prevents the hydrolysis of the urea and its transformation to volatile ammonia and $\mathrm{CO}_{2}$, which would result in the loss of nitrogen and $\mathrm{CO}_{2}$ into the atmosphere and bad odor [19].

Vermicomposting is an established process for the treatment of organic solid wastes or fecal matter. It is an aerobic decomposition process of the pre-digested materials by the combined action of earthworms and microorganisms. In TPS, lacto-fermented urine, feces and kitchen and garden wastes (optionally lacto-fermented) can all be vermi-composted together either in a closed composting chamber or in open vermicomposting heaps. If the charcoal mixture hasn't been added yet, it can be added now to the compost chamber or heap. The addition of charcoal is very important as it is the key factor for the black carbon content in Terra Preta soils, the soil structure (air, water retention), its fertility and the abundance of microbial life.

Figure 5. Overview of the application of Terra Preta Sanitation (TPS) to urine diversion toilets [20].

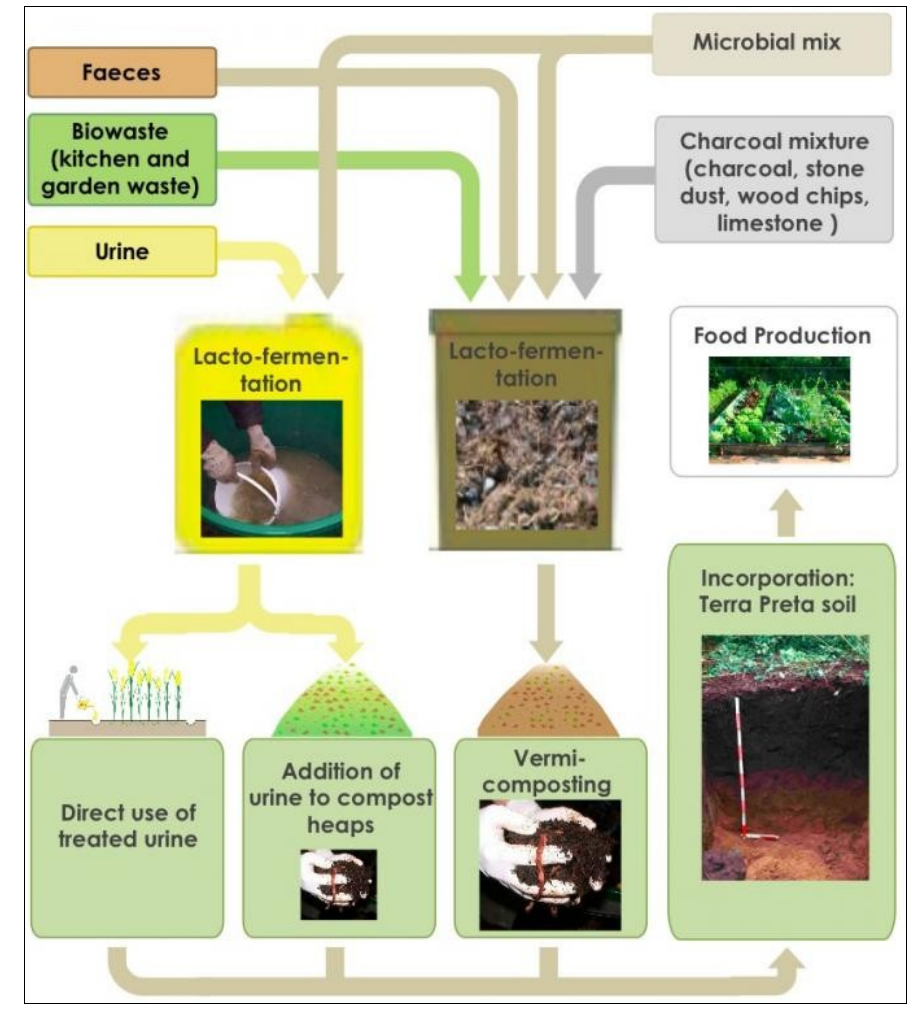

According the scheme showed in Figure 5, four type of options reuse can be obtained: (1) direct use of urine; (2) urine composting; (3) comfrey production and; (4) vermicomposting of lacto-fermented feces.

With reference to the first type, urine can be used as a liquid nitrogen-rich fertilizer with the advantage of having no odor as well as ammonia loss.

For the second type, urine can be applied to a mix of a finely sliced wood source $(80 \%)$, ground charcoal power (10\%) and existing soil (10\%). The amount of urine used must be such as the mixture moisture is in the range $40 \%-65 \%$. In fact, highest values ( $>65 \%)$ may hinder the diffusion of oxygen in the compost pile. While, lowest values $(<20 \%-25 \%)$ can stop the biological process. 
Through subsequent vermicomposting the material is converted into humus with no significant nitrogen, phosphorous and potassium losses. In order to have a good vermicomposting process, it is important that some key parameters are in a certain range. According to Factura et al. [6], the temperature of lacto fermented matter must be around $20{ }^{\circ} \mathrm{C}$ while the $\mathrm{pH}$ varies in the range 7.5-8.2. Another important aspect concerns the presence of toxic substances to earthworms. At that regard, the release of ammonia $\left(\mathrm{NH}_{3}\right)$, known for its toxicity to living organisms, is a possible cause of death for worms [6].

With reference to the third type, urine is applied to the Comfrey (Symphytum officinale). Comfrey can take up huge amounts of nutrients and subsequently can be added to the compost, used as mulch or as liquid fertilizer.

Finally, the decomposition of lacto-fermented feces generates a nutrient-rich vermicast product with properties similar to Terra Preta soils. To enhance these processes, an inoculum with a mixture of microorganisms must be carried out as reported in Factura et al. [6].

The effective mixture of microorganisms needed for the lacto-fermenting process is available commercially. But the mix is often expensive and spoils after some weeks as they are manipulated for commercialization. The easiest way to obtain an effective microbial mix is probably to take an inoculum from Sauerkraut (pickled sour cabbage) liquid [6].

Figure 6 shows different type of TPS system management options.

In particular, Figure 6 a represent an action at household level while Figure $6 \mathrm{~b}$ one at community level. Either way, the mixture preparation is the starting point as shown in Figure 6c.

The microbial mixture is fed on a regular basis and it is composed as follows [20]: Bacillus subtilis, Bacillus mesentericus, Geobacillus stearothermophilus, Azotobacter croococcum and Lactobacillus spec. This mixture is specifically designed to prepare for vermicomposting and thus may be better suited than commercial effective microorganism or Sauerkraut liquor. Details about mixture preparation and conservation are reported in Figure 6c.

Regarding the management options, at level of household, urine is used for compost production subsequently applied as fertilizer on the own garden or similar. Fruits and vegetables are then consumed in household. Instead, feces are stored for a month and then subject to the vermicomposting processes with Terra Preta soils formation.

With reference to the community level as for example a rural area, most households and consequently more baths are presented as shown in Figure $6 \mathrm{~b}$.

Feces and urine are collected from households to a processing site through a service provider (with a frequency of 1-4 weeks).

This scenario is not typical of rural areas of underdeveloped countries but also country such as Australia has provided for the use of such technologies as reported in Brown et al. [21].

The first phase regards the production of charcoal powder as well as the microbial mixture subsequently used by households. Instead, Terra Preta and urine compost are applied in agriculture with the possibility to sell them to farmers. 
Figure 6. Terra Preta Sanitation (TPS) management options: (a) Household level; (b) Community level; (c) Microbial mix preparation [21].

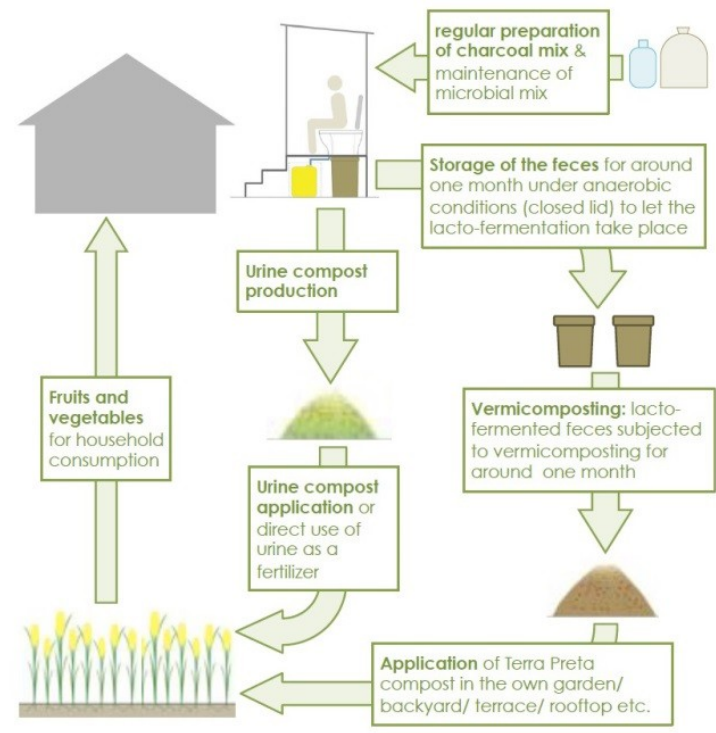

(a)

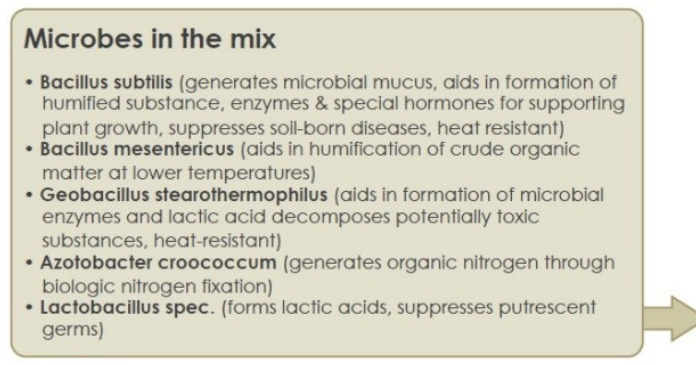

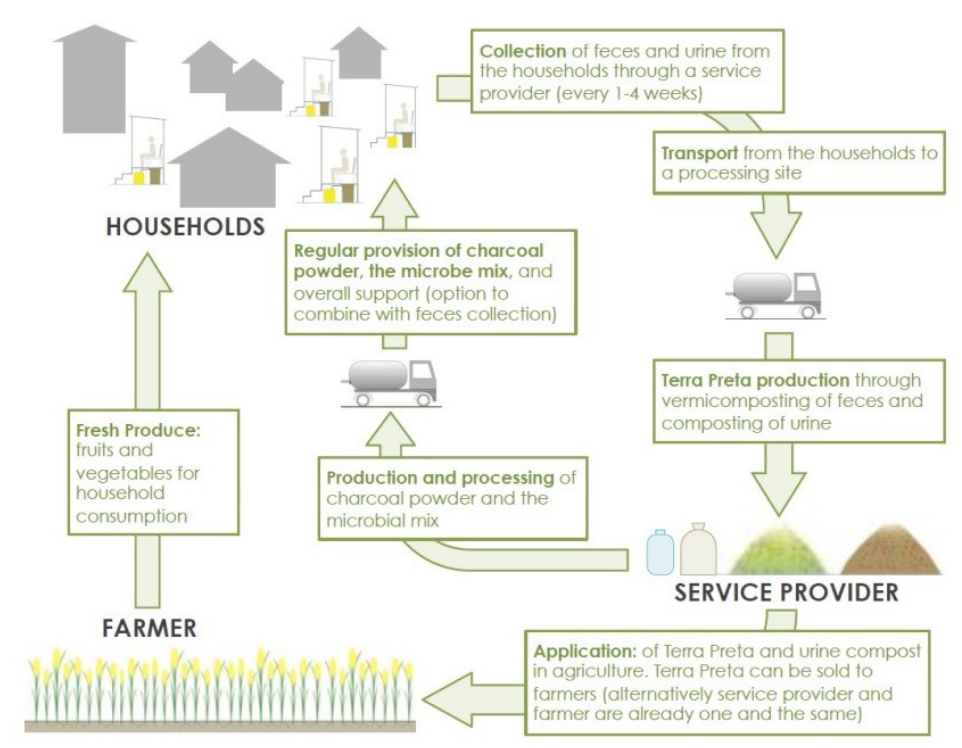

(b)

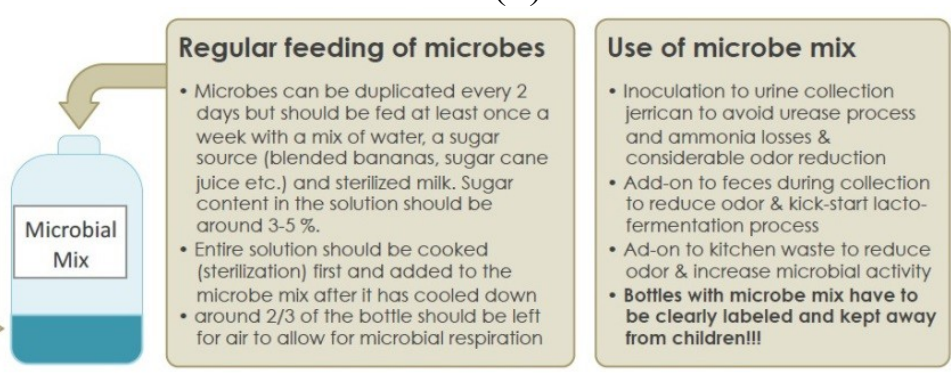

(c)

To close the circle, field's products will be consumed in households as shown in Figure 6b. In these schemes, the charcoal production phase is fundamental as reported in Glaser [7].

Nowadays, the toilet functioning in the pre-Amazonian civilization is not known. Consequently, no information about the inoculum (mixture of microorganisms) is present [7].

Further, a study in the Philippines [22] demonstrated that the TP process of lacto-fermentation, charcoal addition and vermicomposting is efficient in killing pathogens.

It was conducted using twenty UDDTs in Lumbia, Cagayan de Oro City, and Philippines. The users of 10 UDDT toilets were told to add powdered charcoal and $20 \mathrm{ml}$ of the bacterial mix after defecation, while owners of 10 different UDDT toilets were told to just add charcoal [23]. The study was conducted for three months after which the feces from all the UDDT toilets were collected, stored for another 3 months and were then vermicomposted separately for six weeks. Results showed that after 3 months of undergoing the TPS process, fecal material was free of parasite eggs. In Moldova, TP soil was made of fecal matter from UDDT and applied in agriculture showed higher yields for radish and parsley and better performance [24]. 


\subsection{TPS Systems with Flush Water}

There is a number of research applying TPS and flush toilets. The flush toilet is still considered as the standard toilet worldwide which must be acknowledged.

TPS options in case of flush toilets are the following:

- Integrated TPS systems;

- TP made of settled sludge of septic tanks or pour flush toilets;

- TP made of sewage sludge after collection and treatment in a WWTP.

\subsubsection{Integrated TPS System}

The first wet Terra Preta Sanitation pilot system was installed in 2013 in a public toilet in Hamburg as reported in Schuetze et al. [23]. Under usage of low flush toilets, fecal matter is separated by an interceptor with a mesh and a screw. During collection the sludge is charged with fine charcoal, fecal matter is collected and pre-fermented with addition of effective micro organism (containing lactofermenting bacteria). After three month pre-fermentation, the fecal matter is co-composted with a mixture of shredded wood, lawn grass cutting and organic waste (market left over). Efficient composting takes place due to adjusting $\mathrm{C} / \mathrm{N}$ ratio. Thermal and vermicomposting has been tested with promising results but the research is ongoing.

In Berlin, there is a similar pilot project called Terra Boga using a low flush toilet system like in Hamburg. The TP production is based on lactic acid fermentation of fresh biomass origination from the botanic garden horticulture, together with effective micro organisms, urine, pre-fermented fecal matter and nutrient enriched biochar, e.g., made by carbonization of woodchips [25].

\subsubsection{TP Made of Settled Sludge from Septic Tanks or Pour Flush Toilets}

The mixture of primary and excess sludge of decentralized wastewater treatment units contains a high concentration of nutrients and lower quantities of undesirable substances. Today this sludge has to be transported to a central sewage treatment plant and is treated in an entire cleaning process, using a lot of energy as reported in Libralato et al. [26]. A more sustainable use provides closing cycles of materials. At that regard, the production and use of a fertilizer made of sewage sludge could improve the local energy and resource efficiency and will strengthen the regional economic development and produce regional added value.

Böttger et al. have investigated about the possibility to use in Germany Terra Preta as fertilizer [27]. The examination of legal requirements shows that the current restrictions will be no obstacle because the produced fertilizer complies with the legal German requirements. With reference to the comparison of a large-scale industrial production and a small-scale production, it was determined that the technological and economical advantages of the small variant outweigh the industrial production.

Böttger et al. showed that the examined pharmaceuticals have been degraded, the relevant heavy metals were below the requirement values and the product contains a sufficient amount of nutrients [27]. Therefore, the results demonstrate that Terra Preta from sewage sludge of decentralized units can be used directly as a fertilizer in agriculture. Scheinemann et al. [28] show how the lactic acid 
fermentation of fecal matrices does have a high influence on the native microorganism flora [28]. Bacterial, viral and parasitic pathogens were degraded within a few days to a few weeks under lab conditions. "This could be a very interesting technique for sewage sludge or manure treatment not only for hygienic reasons but also because of the matter loss is drastically reduced compared to composting. Major details about the comparison between lactic acid fermentation and composting are reported in [28].Therefore, the gained fertilizer can help to improve a closed loop recycling management while destroying cycles of infection.

\subsubsection{TP Made of Sewage Sludge}

In this section, some important considerations about the use of sewage sludge in the Terra Preta were presented. Prabhu et al. [29] showed that biomethanation potential (BMP) for the co-digestion of food waste and sludge at 1:2 mixing ratios gave a maximum biogas production of $486 \mathrm{~mL} / \mathrm{gVS}$ with a methane content of $63 \%$. BMP tests were carried out on a mixture generated by a horizontal plug flow anaerobic digester of $60 \mathrm{~m}^{3}$ working capacity [29].

In addition, other laboratory tests using sludge after centrifugation were tried according to the following different ways: (1) sludge (control 1); (2) sludge + charcoal (control 2); (3) sludge + charcoal + EM (Effective Microorganisms for lactic acid production, a commercial product); (4) sludge + charcoal $+\mathrm{EM}+$ Soil and (5) sludge + charcoal $+\mathrm{EM}+$ Soil $+\mathrm{CaCO}_{3}$. The main results produced by Prabhu et al., (2013) highlights how lacto fermentation was carried out for 28 days to improve the sludge characteristics. In samples having EM, no fecal odor was present after lacto fermentation [29]. While, the $\mathrm{C} / \mathrm{N}$ ratio in above five samples decreased from 26, 61, 65, 72 and 61 to 13, 44, 40, 49 and 47, respectively. This was followed by vermicomposting for further refining of the sludge although low values of $\mathrm{C} / \mathrm{N}$ ratio can release ammonia that is toxic to the worms. In fact, Factura et al. [6] show how $\mathrm{C} / \mathrm{N}$ ratio values (expressed in terms of percentage of soluble nitrogen species in lacto fermented faces $(\% \mathrm{~N})$ on dry-matter) in the range of $0.5-1.6$, may restrict the vermicomposting process due to the ammonia release. Today, the effect of the Terra Preta compost made of sewage sludge on plant growth (after vermicomposting), is still being researched as reported in Prabhu et al. [29].

\section{Case Studies}

In this section, several case studies relate to the TPS systems application are reported. To the present, TPS has been scientifically established for kitchen and garden wastes, human feces and human urine. As a toilet system, TPS could be applied to Urine Diversion Toilets (UDDTs), arborloos, fossa alternas or any other kind of composting toilet as reported in Morgan [30].

Generally, the Terra Preta toilets consist of basically four elements: (1) toilet superstructure, which provides shelter for the user and the toilet itself; (2) a urine diversion seat or slab; (3) a urine collection chamber and (4) a feces collection chamber (bucket; vault; etc.).

The superstructure is present since a toilet should be a place of privacy as well as it must protect the toilet from heavy rain, sunshine, wild animals or vandalism.

In addition, the superstructure influences the ventilation system which is crucial for the control of odor and flies breading. Because of the Terra Preta toilets process both feces and urine in an anaerobic 
process in which no gas and odor is produced, there is no need for a special ventilation of the collections chamber and ventilation of the toilet can be limited to the circulation of fresh air in the cabinet or the indoor toilet room.

Urine diversion is a system where urine and feces are separated either in a special pedestal or in a squat plate. The urine is fed off through a pipe to a plastic container and the feces drop into a vault where soil or wood ash or both are added.

This has the effect of partially dehydrating the feces which makes them easier to handle. The advantage of urine diversion is that urine can be collected separately and used to increase the production of green vegetables, maize, pumpkin and other valuable food items.

The second advantage to urine diversion is that the feces are far more easily handled and dehydrated, as they are not mixed with urine. As reported in Gensch [31], about half a liter (for a $20 \mathrm{~L}$ jerrican) of the microbial mix should be added to the urine container prior the collection. The microbial mix prevents the bacterial urease process and consequently no volatile ammonia is produced, resulting in almost no odor, a reduced loss of nitrogen into the atmosphere and the conversion of $\mathrm{N}$ in the urine, leading to higher fertilization potential [31].

As regards feces, almost any sealable bucket can be used as a feces collection chamber. The most important feature of the feces collection chamber is its air-tightness to make sure that there are anaerobic conditions for lacto-fermentation.

The most simple collection chamber is a bucket, placed under a toilet seat. Thus, not only the collection chamber/bucket should be airtight but also the toilet seat or squatting hole needs to be sealable. After each defecation, a charcoal mix needs to be added to cover the feces.

Charcoal removes the bad odour of the feces and provides stable organic matter for the Terra Preta soil production. Sliced-cut wood is used as a bulking agent and to raise the $\mathrm{C} / \mathrm{N}$ ratio in order to create a substrate, which will be accepted by the earthworms [6]. Further information regarding the use of the toilets are reported in Factura et al. [6] in particular to initiate the lacto-fermentation process in the feces collection chamber/bucket.

Figure 7 and Figure 8 show, respectively, some examples of embodiment relating to the African context. In particular, Figure $7 \mathrm{a}-\mathrm{d}$ show the case study of a UDDT toilet in Paje, Botswana. It is observed how urine is used in agriculture as fertilizer (Figure 7d). While, Figure 7 e-g show an example of double vault urine diversion toilet in Malawi highlighting how also for this case, that urine is used in agriculture (see Figure 7f).

More complex and expensive realizations are those reported in Figure 8. In particular, Figure 8 a-c show the UDDT complex realized at the Holy Rosary School in Pujehun (Sierra Leone). Another example of sanitation system for a school is that shown in Figure 8d concerning the Rwanda. This complex was realized by the United Nations International Children's Emergency Fund (UNICEF) Sustainable Sanitation Program. Finally, Figure 8e and 8f describe the public complex constituted by UDDTs toilets. In this system, feces are collected and sanitized to be used as fertilizers in tree plantations (see Figure 8f).

The case studies addressed show how the most basic Terra Preta toilet does not require more than a sealable bucket for feces; a urinal; the microbial mix; the charcoal mix and space for vermicomposting. Thus, there is a high potential for low-cost solutions even though a well-established urine diversion 
toilet (which is also convenient for woman, children and elderly people) should be considered as the minimal standard for long-term solutions.

In addition, Terra Preta toilets could be constructed as a high-tech alternative to conventional sanitation systems in multi-story houses as well as at the household level becoming an attractive option even for developed countries.

Figure 7. Case studies: (a) UDDT toilet in Paje, Botswana; (b) A woman demonstrates the use of the toilet; (c) Toilet for feces; (d) Garden where the urine is used to fertilize the plants (photos (a), (b), (c), (d) by Stefanie Lorenz); (e) Double vault urine diversion toilet in Malawi; (f) Tree nursery linked to the Ecosan program; (g) Double vault urine diversion toilet in Northern Malawi (photos (e), (f), (g) by Peter Morgan).

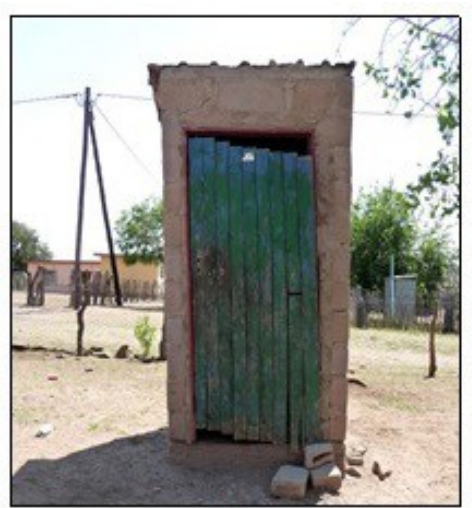

(a)

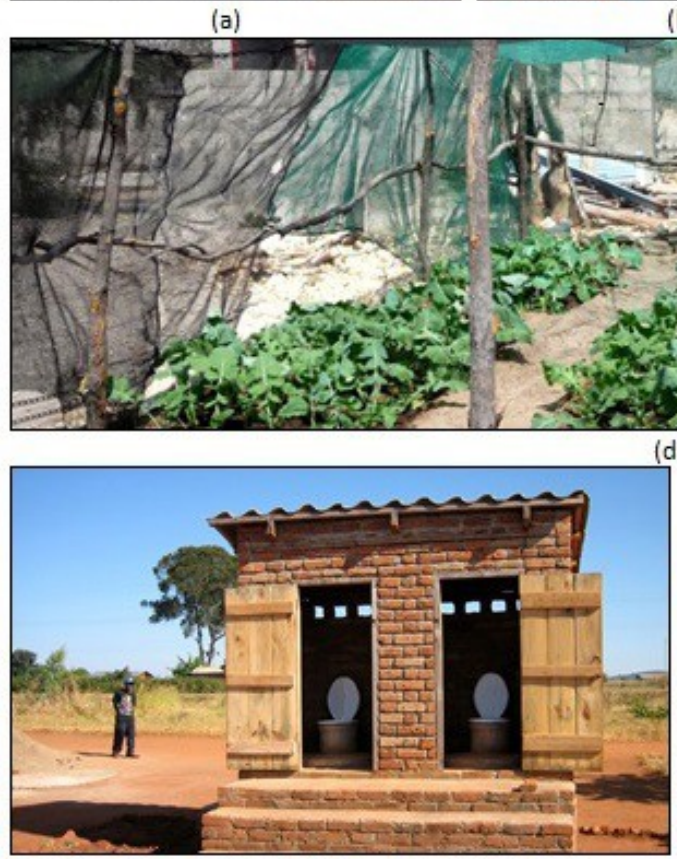

(e)

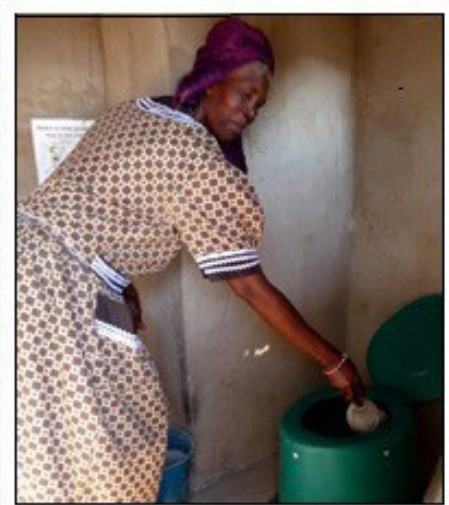

(b)

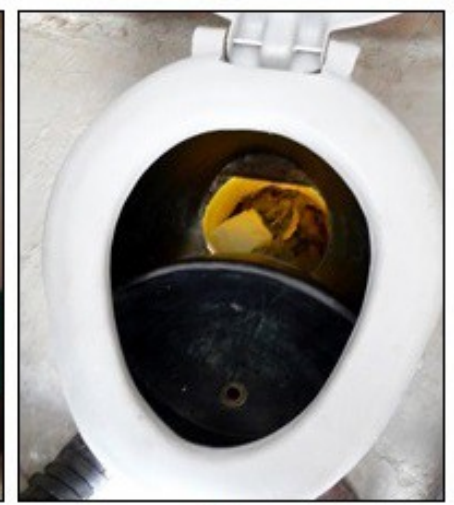

(c)

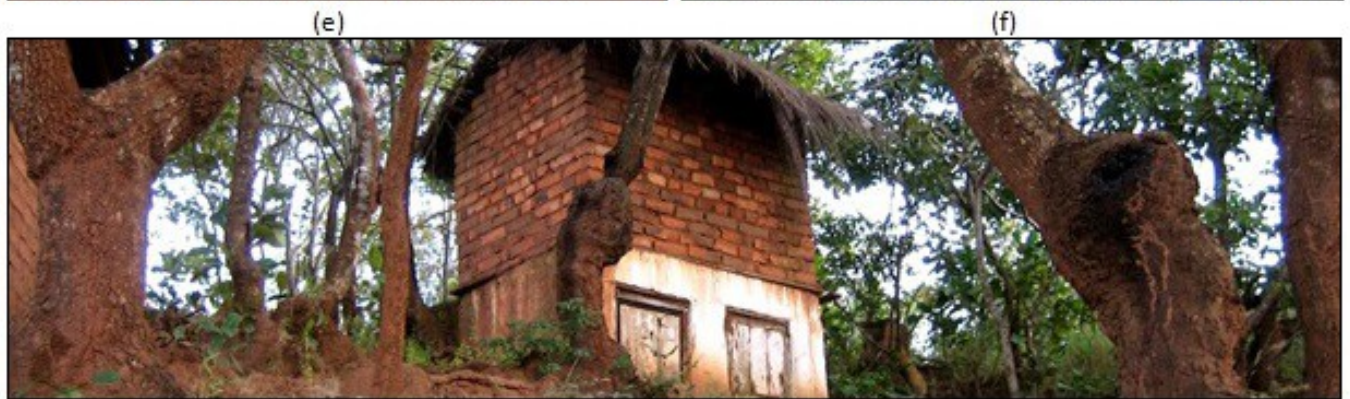

(g)

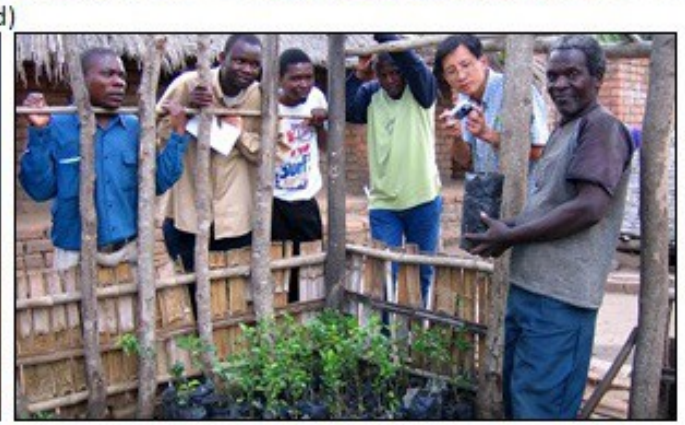


Figure 8. Case studies: (a) Outside view of the UDDT complex showing four separate "ecosan pods" at Holy Rosary School, Pujehun, Sierra Leone; (b) Particular of the brick structure fitted with cement pipe; (c) Particular of the vault door opened to take vault content (for composting) (photos (a), (b), (c) by Richard Napper); (d) UDDT complex in a school of Rwanda supported by UNICEF Sustainable Sanitation Program. Particular of the vault door as in the case of Figure 8c (photo by Guy Mbayo Kakumbi); (e) Rwanda, biogas and UDDT projects. Particular of the UDDT complex located in a public place; (f) Feces are used as fertilizers in tree plantations as well as Kigaly City Gardens, Rwanda. (photos (e), (f) by Eugene Dusingizumuremyi).

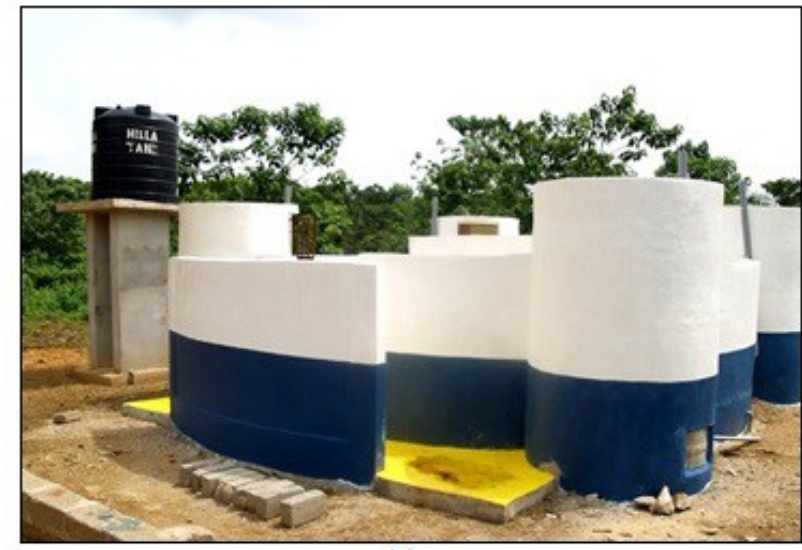

(a)

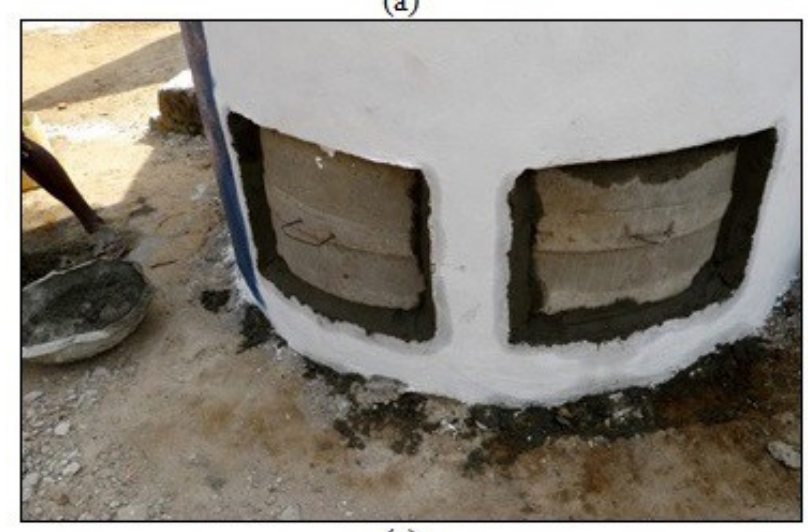

(c)

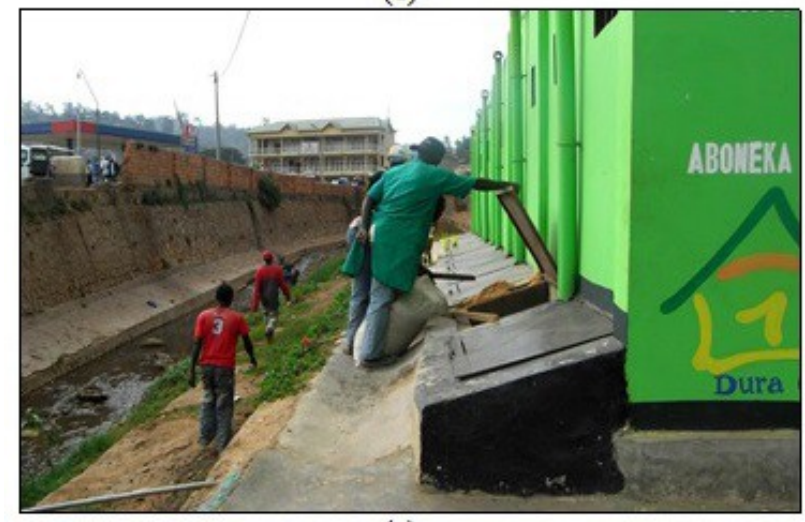

(e)

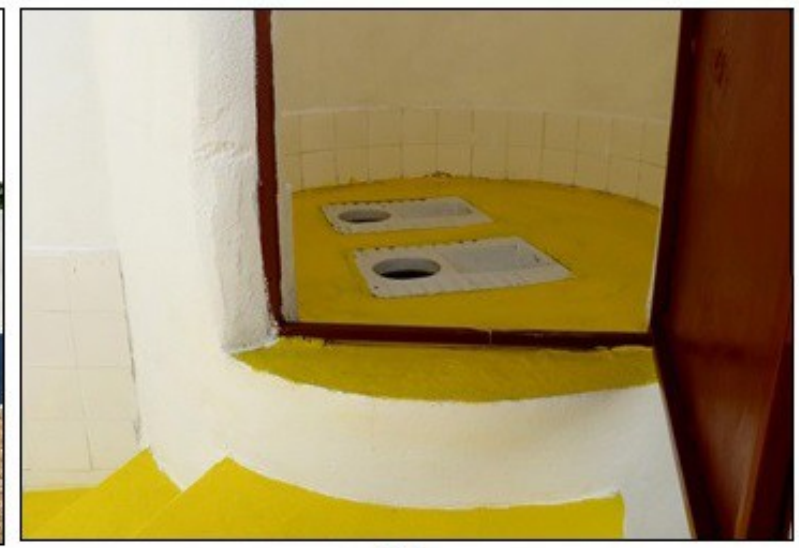

(b)

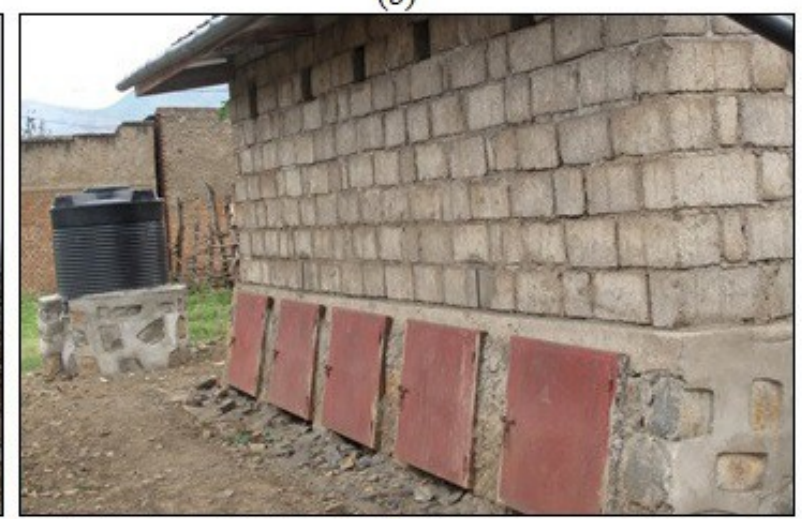

(d)

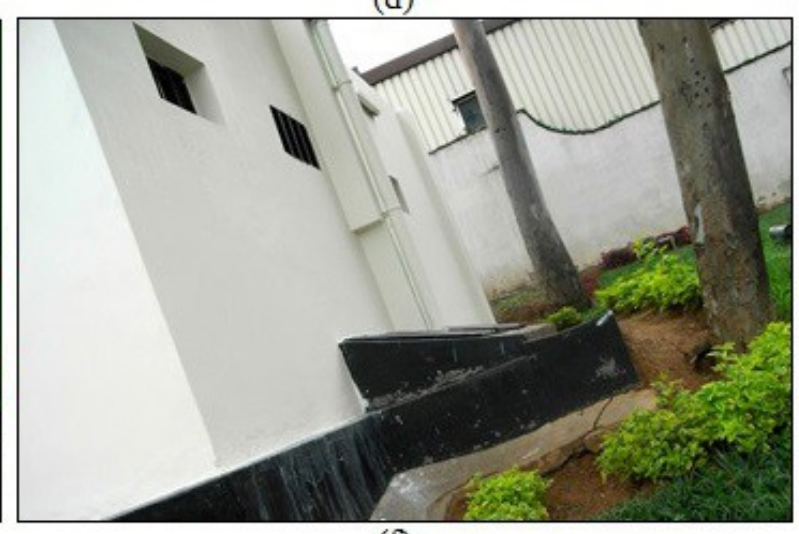

(f) 


\section{Conclusions}

In order to reach the Millennium Development Goals for significantly reducing the number of people without access to adequate sanitation, new holistic concepts are needed focusing on economically feasible closed-loop ecological sanitation systems rather than on expensive end-of-pipe technologies.

In particular, the following outcomes can be pointed out:

- An analysis of a former civilization in the Amazon (nowadays Brazil) highlights the possibility to close the loop with a more sustainable lifestyle integrating soil fertility, food security, waste management, water protection and sanitation, renewable energy;

- TPS System is the name of the concept, which aims to use this technology for a safe and recycling-oriented treatment of wastes;

- TPS System can be implemented in different steps of the sanitation chain. Major driver for TPS is the efficient use of organic matter as well as macro and micro nutrients;

- In light of decreasing soil fertility and humus quality worldwide and desertification, TPS can play an important role to solve the sanitation problem and sustainable soil management, which leads to increased food security.

\section{Acknowledgments}

The authors would like to thank Sacha A. Berardo for his English revision and two anonymous reviewers for their precious suggestions. Furthermore, we acknowledge the financial support from the Emilia-Romagna government through the Technopoles Programme.

\section{Author Contributions}

We declare that Sabino De Gisi is the main author of this manuscript. All authors substantially contributed to the conception and design of this study, regularly reviewed the methodology and earlier versions of the manuscript and critically revised the final draft.

\section{Conflicts of Interest}

The authors declare no conflict of interest.

\section{References}

1. Water Sanitation and Health. Global Water Supply and Sanitation Assessment 2000 Report. Available online: http://www.who.int/water_sanitation_health/monitoring/jmp2000.pdf (accessed on 25 October 2013).

2. Post Sanitation Proposal for Overall Vision, Summary Targets, Detailed Targets, Indicators and Definitions. Available online: http://www.wssinfo.org/fileadmin/user_upload/resources /Post-2015-proposal-for-Sanitation-Targets-and-Indicators_-December-2012_proposed-revisions_ final.pdf (accessed on 25 October 2013). 
3. Werner, A.; Panesar, A.; Rüd, S.B.; Olt, C.U. Ecological sanitation: Principles, technologies and project examples for sustainable wastewater and excreta management. Desalination 2009, 248, 392-401.

4. De Feo, G.; Laureano, P.; Drusiani, R.; Angelakis, A.N. Water and Wastewater Management Technologies through the Centuries. Water Sci. Technol. 2010, 10, 337-349.

5. Bond, T.; Roma, E.; Foxon, K.M.; Templeton, M.R.; Buckley, C.A. Ancient water and sanitation systems - applicability for the contemporary urban developing world. Water Sci. Technol. 2013, 67, 935-941.

6. Factura, H.; Bettendorf, T.; Buzie, C.; Pieplow, H.; Reckin, J.; Otterpohl, R. Terra Preta sanitation: Re-discovered from an ancient Amazonian civilization-Integrating sanitation, bio-waste management and agriculture. Water Sci. Technol. 2010, 61, 2673-2679.

7. Glaser, B. Prehistorically modified soils of central Amazonia: A model for sustainable agriculture in the twenty-first century. Philos. Trans. R. Soc. Biol.Sci. 2007, 362, 187-196.

8. Terra Preta. Available online: http://www.gerhardbechtold.com/TP/gbtp.php (accessed on 20 December 2013).

9. Brewer, C.E.; Brown, R.C. Biochar. In Comprehensive Renewable Energy, 1st ed.; Sayigh, A., Ed.; Elsevier: Philadelphia, PA, USA, 2012; Volume 5, pp. 357-384.

10. Tollefson, J. Amazon ecology: Footprint in the forest-Researchers are tracking just how much impact ancient peoples had on the Amazon. Nature 2013, 502, 160-162.

11. International Biochar Initiative. Available online: http://www.biochar-international.org/biochar/ soils (accessed on 20 December 2013).

12. Steiner, C.; Teixeira, W.; Lehmann, J. Long term effect of manure, charcoal and mineral fertilization on crop production and fertility on a highly weathered Central Amazonian upland soil. Plant Soil 2007, 291, 275-290.

13. Umlingo Solutions. Available online: http://umlingosol.co.za/biochar.html (accessed on 20 December 2013).

14. Herzen, B.; Talsma, L. Conversion of Human Waste into Biochar Using Pyrolysis at a Community-Scale Facility in Kenya-Various Documents on Results from Research Grant; Stanford University and The Climate Foundation: Stanford, CA, USA.

15. Wendland, C.; Deegener, S.; Jorritsma, F. Experiences with urine diverting dry toilets (UDDTs) for households, schools and kindergarten in Eastern Europe, the Caucasus and Central Asia (EECCA). Sustain. Sanit. Pract. 2011, 6, 16-22.

16. Shalabi, M. Vermicomposting of Faecal Matter as a Component of Source Control Sanitation. Ph.D. Thesis, Technical University of Hamburg, Hamburg, Germany, 2006.

17. Taricska, J.R.; Long, D.A.; Chen, J.P.; Hung, Y.T.; Zou, S.W. Anaerobic digestion. In Biosolids Treatment Processes; Wang, L.K., Shammas, N.K., Hung, Y.T. Eds.; Humana Press Inc.: New York, NY, USA, 2007; Volume 6, pp. 177-205.

18. Madigan, M.; Martinko, J. Brock Biology of Microorganisms, 11th ed.; Pearson Prentice Hall: Upper Saddle River, NJ, USA, 2006.

19. SSWM (Sustainable Sanitation and Water Management). Available online: http://www.sswm.info/ category/implementation-tools/water-use/hardware/toilet-systems/terra-preta-toilet (accessed on 29 January 2014). 
20. Kim, J.S.; Sparovek, G.; Longo, R.M.; de Melo, W.J.; Crowley, D. Bacterial diversity of terra preta and pristine forest soil from the Western Amazon. Soil Biol. Biochem. 2007, 39, 684-690.

21. Brown, V.; Jakson, D.W.; Khalifé, M. Melbourne metropolitan sewerage strategy: A portfolio of decentralised and on-site concept designs. Water Sci. Technol. 2009, 62, 510-517.

22. Itchon, G.; Miso, A.; Gensch, R. The effectivity of the Terra Preta Sanitation (TPS) process in the elimination of parasite eggs in fecal matter: A field trial of Terra Preta Sanitation in Mindanao, Philippines. In Proceedings of the 1st International Conference on Terra Preta Sanitation, Hamburg, Germany, 28-31 August 2013.

23. Schuetze, T.; Lee, J.W.; Lee, T.G. Sustainable Urban (re-)Development with Building Integrated Energy, Water and Waste Systems. Sustainability 2013, 5, 1114-1127.

24. Andreev, N.; Boincean, B.; Ronteltap, M.; Lens, P.N.L. The effect of terra preta like substrate on germination and shoot growth of radish and parsley. In Proceedings of the 1st International Conference on Terra Preta Sanitation, Hamburg, Germany, 28-31 August 2013.

25. FU Berlin Terra Boga Projekt. Available online: http://www.terraboga.de (accessed on 25 October 2013).

26. Libralato, G.; Ghirardini, A.V.; Avezzù, F. To centralise or to decentralise: An overview of the most recent trends in wastewater treatment management. J. Environ. Manage. 2012, 248, 61-68.

27. Böttger, S.; Töws, I.; Bleicher, J. Terra Preta-Production from sewage sludges of decentralised wastewater systems. In Proceedings of the 1st International Conference on Terra Preta Sanitation, Hamburg, Germany, 28-31 August 2013.

28. Scheinemann, H.; Dittmar, K.; Erfurt, K.; Stoeckel, F.S.; Krueger, M.E. Hygienisation and nutrient conservation of sewage sludge or cattle manure by fermentation. In Proceedings of the $1 \mathrm{st}$ International Conference on Terra Preta Sanitation, Hamburg, Germany, 28-31 August 2013.

29. Prabhu, M.; Horvat, M.; Lorenz, L.; Otterpohl, R.; Bettendorf, T.; Mutnuri, S. Terra Preta as an alternative for the management of sludge from wastewater treatment plant. In Proceedings of the 1st International Conference on Terra Preta Sanitation, Hamburg, Germany, 28-31 August 2013.

30. Morgan, P. Ecological Toilets-Start Simple and Upgrade from Arborloo to VIP; Stockholm Environment Institute, EcoSanRes Programme: Stockholm, Sweden, 2009. Available online: http://www.ecosanres.org/pdf_files/EcologicalToilets-PeterMorgan-Mar2009.pdf (accessed on 21 January 2013).

31. Gensch, R. Terra Preta Sanitation; Sustainable Sanitation Center: Cagayan de Oro, Philippines, 2010. Available online: http://www.sswm.info/sites/default/files/reference_attachments/GENSCH\% 202010\%20b\%20Terra\%20Preta\%20Sanitation.pdf (accessed on 21 January 2013).

(C) 2014 by the authors; licensee MDPI, Basel, Switzerland. This article is an open access article distributed under the terms and conditions of the Creative Commons Attribution license (http://creativecommons.org/licenses/by/3.0/). 